\title{
AZ ÁRVÍZVÉDELMI FELADATOK ELLÁTÁSÁHOZ A KÖTIVIZIG-NÉL RENDELKEZÉSRE ÁLLÓ ÉS A KÜLSŐ SZERVEZETEKTŐL BEVONHATÓ GÉPI ERŐFORRÁSOK
}

\section{MECHANICAL RESOURCES AVAILABLE AT MIDDLE TISZA DISTRICT WATER DIRECTORATE FOR EXTERNAL FLOOD PROTECTION AND OUTSOURCING}

\author{
Horváth Lajos
}

Közép-Tisza-vidéki Vízügyi Igazgatóság. Szolnok, Magyarország, horvath.lajos@kotivizig.hu

\begin{abstract}
After 1998, the flood waves of the Tisza, Zagyva and Hármas-Körös rivers reached record levels in the area of operation of MTDWD requiring significant mechanical resources from the Water Directorate and participating external organizations in order to perform the protection tasks. In this article, the author describes the volume of mechanical resources used in the management of the MTDWD and the volume of those provided by external organizations during the flood control of the Tisza River in 2000, 2006 and 2010. It proves that in the event of flood defenses exceeding the order level, the Directorate's own machinery resources are not sufficient, and that therefore, external machinery capacities are indispensable to meet future requirements.
\end{abstract}

Keywords: flood protection, mechanical resource, defense intervention, damage prevention, external forces.

\section{Összefoglalás}

Az 1998. évet követően a KÖTIVIZIG működési területét érintően a Tiszán, a Zagyván és a Hármas-Körös folyókon levonuló árhullámok több esetben rekordszintet döntöttek. A védelmi feladatok ellátása a vízügyi igazgatóságtól és a közreműködő külső szervezetektől jelentős gépi erőforrást igényelt. A cikkben a szerző ismerteti a 2000., 2006. és 2010. évi tiszai árvízvédekezés során az igazgatóság védekezési területén igénybe vett, a KÖTIVIZIG vagyonkezelésében lévő, valamint a külső szervezetek által biztosított gépi erőforrások volumenét. Bizonyítja, hogy az elrendelési fokozatot meghaladó árvízvédekezések alkalmával az igazgatóság saját gépi erőforrása a szükséges mértékben nem áll rendelkezésre, ezért a feladatok maradéktalan elvégzése érdekében elengedhetetlen a külső gépi kapacitások igénybevétele.

Kulcsszavak: árvízvédelem, gépi erőforrás, védelmi beavatkozás, kárelhárítás, külső erők.

\section{Bevezetés}

Az árvízvédelmi feladatokat ellátó vízügyi igazgatóságok a 90’-es éveket követően jelentős szervezeti átalakuláson mentek keresztül. A szervezethez tartozó építési és kivitelezési részlegek megszüntetésre vagy átszervezésre kerültek. Ebből adódóan az igazgatóság gépi kapacitása jelentősen lecsökkent, és jelenleg már nem rendelke- zik megfelelő mennyiségű és minőségű technikai eszközökkel a vízkárelhárítási tevékenység teljes körű ellátásához. A hiányzó gépi erőforrás biztosításához elengedhetetlen olyan külső szervezetek bevonása, amelyek rendelkeznek a szükséges technikai eszközökkel. (Például: a katasztrófavédelem, a honvédség, a rendvédelmi szervek, kivitelezői cégek, egyéni vállalkozók, szolgáltatók stb.) 
A téma aktualitását bizonyítja, hogy az elmúlt évtizedek árvízvédekezései során minden esetben jelentős mennyiségben kellett bevonni külső gépi erőforrásokat, mert az érintett igazgatóságok nem rendelkeztek a védekezéshez szükséges elegendő technikai gépekkel, eszközökkel.

Számolni kell azzal a lehetőséggel, hogy a Tiszán az elmúlt évtizedekben kialakult árhullámoknál magasabb árhullámok is levonulhatnak [1], ezért fel kell készülni ezek kivédésére és a lakosság árvízbiztonságát megteremtő beavatkozások elvégzésére.

A hazai szakirodalomban gyakran jelennek meg hazánk árvízi védekezésének helyzetével foglalkozó publikációk, azonban ezek nem vizsgálják a vízügyi ágazat gépi erőforrásának helyzetét, nem kutatják és tárják fel a védekezés során felmerülő gépi és technikai eszközök hiányának külső erőforrásokból történő pótlásának lehetőségét, mértékét.

Ebben a cikkben bemutatom a KÖTIVIZIG területén a 2000., 2006. és 2010. években levonult árhullámok esetében az árvízvédekezési munkák során alkalmazott gépi erőforrásokat, továbbá vizsgálom és bemutatom, hogy a mértékadó árvízszint (továbbiakban: MÁSZ), valamint a legnagyobb vízszint (továbbiakban: LNV) esetén milyen gépi erőforrás-szükséglettel kell számolni. A cikk megírásának célja, hogy bizonyítsam és egyben felhívjam a figyelmet arra, hogy az elmúlt árvízvédekezések során és egy prognosztizált, jövőbeli árhullám esetében, a vízügyi igazgatóság belső gépi erőforrása a védekezési munkákhoz nem elegendő. Eddig is szükség volt, és fejlesztések nélkül a jövőben is számolni kell azzal, hogy a hiányt külső szervezetek gépi és technikai eszközeinek igénybevételével lehet és kell pótolni.

A felkészülési időszakban elengedhetetlen az erőforrás-szükségletek felmérése, esetleges előretörténő lebiztosítása előszerződések és együttműködési megállapodások megkötésével. A szükséges erőforrás biztosításához elengedhetetlen az „Erőforrás-igénybevételi terv” elkészítése és évenkénti aktualizálása, melynek tartalmaznia kell a külső erők esetében rendelkezésre álló gépeket, valamint a kapcsolattartói elérhetőséget is. A védekezési munkák megkezdésekor sem idő, sem személyi kapacitás nem áll majd rendelkezésre ahhoz, hogy akkor kerüljön felmérésre és megszervezésre a szükséges gépi rendelkezésre állás.

\section{Az árvízvédekezési feladatok ellá- tásához szükséges gépi erőforrás igények a KÖTIVIZIG területén}

Az árvízvédekezési munkák végrehajtása során a humán erőforrás mellett számos munkagép, gépjármű, tehergépkocsi, speciális szállítójármü, vízi jármű és az ezekhez szükséges egyéb eszközök kerülnek igénybevételre. Főként a védekezéshez szükséges anyag mozgatásához és a nagyszámú fizikai munkás beavatkozási helyekre történő szállítása a legnagyobb volumenű, megoldandó logisztikai feladat. Nehezítő körülmény, hogy az észlelt árvízi jelenségek helyei és így a beavatkozási helyszínek területileg eltérőek. A KÖTIVIZIG esetében a kijelölt elsőrendű árvízvédelmi fővédvonal hossza összesen 707,114 km. A figyelőszolgálat által észlelt árvízi jelenségek (pl. buzgár, csurgás, talpszivárgás, rézsűcsúszás stb.) műszaki minősítését követően, a szakasz védelemvezetője döntést hoz a beavatkozás módjáról és megkezdéséről. Amennyiben azonnali beavatkozásra van szükség, meg kell kezdeni a fizikai munkások mozgósítását, valamint a védelmi anyagok helyszínre szállítását.

A védelmi munkák ellátásához rendelkezésre álló, a vízügyi igazgatóság saját állományú gépparkja 2020. január 1-én a következő:

-86 db terepjáró képességű 3,5 t össztömeg alat-

ti személy- és tehergépjármű;

- 67 db mezőgazdasági vontató;

- 5 db építőipari munkagép;

- 31 db vízi jármű (hajó, csónak, rocsó).

A vízügyi igazgatóság a működési területére vonatkozóan minden év február 28-ig, védelmi szakaszonként, elkészíti a felkészülési tervét. A felkészülési terv tartalmazza az előre meghatározott árhullámszintekre történő beavatkozási feladatokat, valamint azok humán, gépi és védelmianyag-igényeit.

Az 1. táblázat a 2019. évi felkészülési terv [2] alapján az árvízvédekezési beavatkozásokhoz szükséges gépek számát mutatja három különféle tetőző árhullámszint bekövetkezése esetén

A kijelölt tetőző árhullámszintek a szolnoki vízmércén a következők: „régi” MÁSZ: 974 cm, LNV: $1041 \mathrm{~cm}$ és MÁSZ: $1085 \mathrm{~cm}$. Ezen vízszintek azért kerültek kijelölésre, mert az árvízvédekezések során felkészülési tervezési szintnek és egyben mértékadónak tekinthetőek. A „régi” MÁSZ vízszintje a 74/2014. (XII. 23.) BM-rendelet a folyók mértékadó árvízszintje [3] érvénybe lépése előtti érték. 
1. táblázat. Az árvízvédekezéshez szükséges gépi eröforrások a tetőző árhullám szintjének függvényében a KÖTIVIZIG területén.

\begin{tabular}{|c|c|c|c|}
\hline $\begin{array}{c}\text { Géptípusok } \\
\text { [db] }\end{array}$ & $\begin{array}{l}\text { „régi” } \\
\text { MÁSZ }\end{array}$ & LNV & $\begin{array}{l}\text { „új”” } \\
\text { MÁSZ }\end{array}$ \\
\hline Munkagép & 232 & 330 & 1114 \\
\hline Autó, daru & 5 & 22 & 57 \\
\hline Tehergépkocsi & 1426 & 2071 & 6630 \\
\hline Mg-i vontató & 163 & 217 & 137 \\
\hline Vizi jármű & 21 & 24 & 27 \\
\hline Egyéb jármű & 6 & 6 & 7 \\
\hline
\end{tabular}

Az „új” MÁSZ 1\%-os valószínűséggel várható vízállásértékének meghatározása a vízhozamidősorok statisztikai elemzésével az 1\%-os valószínűséggel számított vízhozamból indult ki, amelyhez a legutóbbi árvizek adatait is magában foglaló, hosszú távú idősorok szolgáltattak alapadatokat..

$\mathrm{Az}$ 1. táblázatban szereplő gépigény mennyiségéből látható, hogy a vízügyi igazgatóság saját állományú gépparkja tekintetében csak a vízi járművek esetében rendelkezik kellő mértékű kapacitással. A rendelkezésére álló 86 db személy- és tehergépjármű az irányítási feladatok ellátására sem elegendő, hiszen III. fokozatú árhullám esetén már 100 fő feletti védekezésirányítói létszám részére kell biztosítani jármüvet.

$\mathrm{Az}$ árvízvédelmi készültségi fokozatok elrendelési szintjei a Tisza szolnoki vízmércéjén („0” pont: 78,78 mBf) mért vízállásai alapján a következőek: I. fok: $650 \mathrm{~cm}$; II. fok: $750 \mathrm{~cm}$; III. fok: 800 $\mathrm{cm}$.

Az 1. táblázatban jól látható, hogy a közúti járművek (tehergépkocsik) az árvízvédekezéshez szükséges gépek legnagyobb részét, 77-83\%-át teszik ki, ezért rendelkezésre állásuk alapvető feltétele a sikeres árvízvédekezésnek.

A felkészülési tervben szereplő gépigény és a vízügyi igazgatóság saját gépi állománya ismeretében kijelenthető, hogy a védekezési feladatok ellátására külső erők gépi erőforrásának bevonása szükséges, mivel a vízügyi igazgatóság saját kapacitása nem elegendő.

\section{A 2000., 2006. és 2010. évi tiszai árvíz- védekezések során alkalmazott gépi erőforrások}

A fejezetben az árvízvédekezési jelentésekből [4] származó napi és összegzett gépek mennyiségi adatait táblázatokba rendezve mutatom be, és vizsgálom a külső erők által biztosított gépi erőforrások, valamint a KÖTIVIZIG saját képességének arányát a 2000., 2006., 2010. árvízvédekezések alkalmával. A külső erők gépi mennyiségi adatai az igazgatósággal előszerződött és együttmüködési megállapodást kötött külső szervezetek gépi állományára vonatkoznak.

A 2. táblázatban kimutatott adatok alapján megállapítható, hogy a 2000. évi árvízvédekezés idején volt bevonva a legnagyobb gépi erőforrás (27 $963 \mathrm{db}$ ) és legnagyobb arányban (93\%) a külső erők gépi kapacitása. A három árhullám közül a 2000. évi tetőzött a legmagasabb, $1041 \mathrm{~cm}$ szinten Szolnoknál (2006: 1013 cm, 2010: $954 \mathrm{~cm}$ ).

2. táblázat. A 2000., 2006. és 2010. évi árvízvédekezésekben alkalmazott gépi erőforrások teljes védekezés idejére összegzett adatai a KÖTIVIZIG területén.

\begin{tabular}{|c|c|c|c|}
\hline Gépek & $\mathbf{2 0 0 0 .}$ & $\mathbf{2 0 0 6 .}$ & $\mathbf{2 0 1 0 .}$ \\
\hline $\begin{array}{c}\text { KÖTIVIZIG } \\
\text { [db] }\end{array}$ & $\begin{array}{c}2022 \\
\mathbf{( 7 \% )}\end{array}$ & $\begin{array}{c}2684 \\
\mathbf{( 1 5 \% )}\end{array}$ & $\begin{array}{c}2310 \\
\mathbf{( 1 8 \% )}\end{array}$ \\
\hline $\begin{array}{c}\text { Külső erők } \\
\text { [db] }\end{array}$ & $\begin{array}{c}25941 \\
(93 \%)\end{array}$ & $\begin{array}{c}14837 \\
\mathbf{( 8 5 \% )}\end{array}$ & $\begin{array}{c}10790 \\
(82 \%)\end{array}$ \\
\hline $\begin{array}{c}\text { Összesen } \\
\text { [db] }\end{array}$ & 27963 & 17521 & 13100 \\
\hline
\end{tabular}

A kijelölt árvízvédelmi fővédvonalakon a védelmi munkák ellátását minden esetben a területileg illetékes vízügyi igazgatóság szervezi és irányítja. A szükséges többletkapacitást az előre tervezett módon használja fel, és gondoskodik annak biztosításáról, valamint az ágazaton belüli átvezényléseket az Országos Műszaki Irányító Törzsön keresztül kérelmezi. A társszervezetek bevonását (pl.: honvédség, rendvédelmi szervek) a Megyei Védelmi Bizottságokon keresztül lehet igényelni.

A 3. táblázatban feltüntetett napi maximális adatokból is jól látható a külső erők által biztosított gépek jelentős aránya.

3. táblázat. A 2000., 2006. és 2010. évi árvízvédekezésekben alkalmazott gépi eröforrások napi maximális adatai a KÖTIVIZIG területén.

\begin{tabular}{|l|c|c|c|}
\hline Gépek & $\mathbf{2 0 0 0 .}$ & $\mathbf{2 0 0 6 .}$ & $\mathbf{2 0 1 0 .}$ \\
\hline KÖTIVIZIG & 05.01. & 04.28. & 06.03. \\
[db] & 59 & 78 & 56 \\
\hline Külső erők & 04.18. & 04.09. & 06.11. \\
[db] & 1181 & 601 & 602 \\
\hline Összesen & 04.18. & 04.09. & 06.11. \\
[db] & 1233 & 654 & 650 \\
\hline
\end{tabular}

$\mathrm{Az}$ 1. ábra szemlélteti a védekezések során igénybe vett külső szervezetek által biztosított gé- 


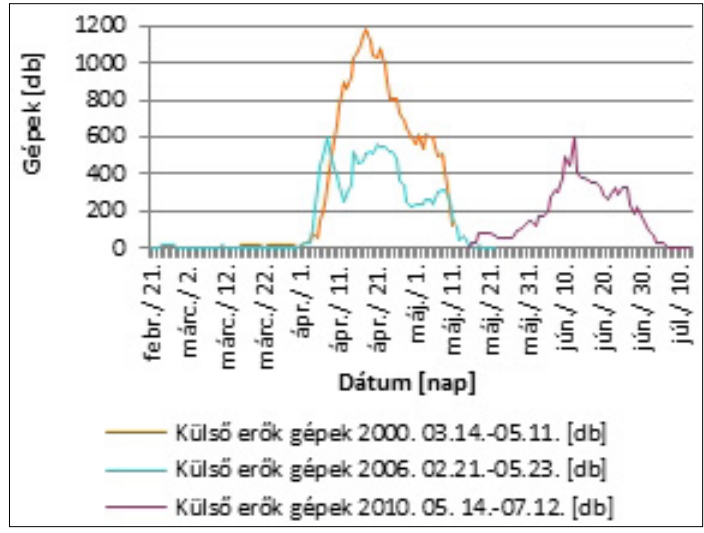

1. ábra. A 2000., 2006. és 2010. évek árvízvédekezésében alkalmazott külső erők gépeinek napi mennyiségi adatai

pek számát, melynek maximuma 2000-ben megközelítette az 1200 darabot.

A védekezés során igénybe vett gépek kimagasló számának hirtelen emelkedése az árhullám emelkedésével egyenes arányban változott, mert a meredeken emelkedő vízállás következtében a figyelőszolgálat nagy számban észlelt káros árvízi jelenségeket, melyek elhárításához védelmi beavatkozásokra került sor. Ezért több szállítójárműre volt szükség a védelmi anyagok és a fizikai munkaerő helyszínre szállítása érdekében.

\section{Következtetések}

Megállapítható, hogy a KÖTIVIZIG a rendelkezésére álló saját állományú gépi kapacitásával az árvízvédelmi munkákat magasabb fokozatú árvízszintet meghaladó árhullámok esetében nem képes ellátni.

A rendkívüli árhullámok levonulása esetén a sikeres árvízvédekezés, valamint a lakosság árvízbiztonságának megteremtése érdekében a vízügyi ágazatba jelentős számú külső gépi erőforrás bevonására van szükség.
A KÖTIVIZIG a védelmi munkák irányítása és ellátása mellett párhuzamosan végzi a normál „békebeli” igazgatási, üzemeltetési, szakfelügyeleti stb. alapfeladatát is, melyhez szintén kapcsolódik gépjárműigény, ezért nem vonható be teljes mértékben az igazgatóság gépjárműparkja a védelmi feladatok végrehajtásába.

A három vizsgált árhullám esetében a vízügyi igazgatóság és a külső erők gépi erőforrásainak aránya a tetőző vízállás függvényében változik. A Tisza szolnoki vízmércéjén mért, $1000 \mathrm{~cm}-\mathrm{t}$ meghaladó tetőző vízállása esetében $80-95 \%$ a külső erők gépierőforrás-aránya. Ez egyben azt jelenti, hogy az árvízvédekezési munkák sikeressége jelentősen függ a külső erők által biztosított erőforrásoktól. Amennyiben az igényelt gépek és technikai eszközök nem állnak kellő számban vagy időben rendelkezésre, az rontani fogja az árvízvédekezési munkák hatékonyságát és eredményességét.

A fenti helyzetek kialakulásának elkerülése érdekében javaslom, hogy a jövőben az erőforrás-igénybevételi tervben szereplő gépi igények tervezése az LNV-szintre történjen, valamint nevesíteni kell azokat a külső szervezeteket (erőket), akik szükség esetén ezeket a technikai eszközöket biztosítani tudják.

Javaslom továbbá, hogy az erőforrás-igénybevételi tervek, valamint az alapjául szolgáló előszerződések, együttműködési megállapodások aktualizálása éves rendszerességgel történjen.

\section{Szakirodalmi hivatkozások}

[1] Kovács S., Lovas A., Gombás K.: Magyarország árvízvédelme az integrált vízgazdálkodásban a Tisza folyó példáján. Hidrológiai Közlöny, 96/4. (2016) 6-19.

[2] KÖTIVIZIG: Felkészülési terv. Szolnok, 2019.

[3] Jogtár, 74/2014. (XII. 23.) BM rendelet a folyók mértékadó árvízszintjeiröl. (letöltve: 2019. 11. 30.) https://net.jogtar.hu/jogszabaly?docid=a1400074. bm

[4] KÖTIVIZIG: Árvízvédekezési napi jelentések. Szolnok, 2000., 2006., 2010. 